\title{
HIGH PRESSURE VAPOUR-LIQUID EQUILIBRIUM OF VOLATILES IN SUPERCRITICAL CARBON DIOXIDE
}

\author{
Karina Gurgenova ${ }^{1}$, Rafał Bogeł-Łukasik ${ }^{2}$, Paweł Wawrzyniak ${ }^{1}$ \\ ${ }^{1}$ Łódź University of Technology, Faculty of Process and Environmental Engineering, Department of \\ Heat and Mass Transfer, ul. Wólczańska 213, 90-924 Łódź, Poland \\ ${ }^{2}$ Unidade de Bioenergia, Laboratório Nacional de Energia e Geologia, Estrada do Paço do Lumiar \\ 22, 1649-038 Lisboa, Portugal
}

\begin{abstract}
Binary vapour-liquid equilibrium of thymoquinone and carbon dioxide at the isothermal conditions was carried out at temperature $323.15 \mathrm{~K}$ and pressures from 6 to $10 \mathrm{MPa}$. The experimental data were fitted to the Soave-Redlich-Kwong equation of state. Results could be used for selection of process parameters in separation of volatiles from raw oil or for evaluation of existing separation technologies.
\end{abstract}

Keywords: carbon dioxide, solubility, supercritical, thymoquinone

\section{INTRODUCTION}

Supercritical fluid - liquid equilibrium data play a fundamental role in the design of extraction processes and equipment. Due to its unique physical and chemical properties carbon dioxide $\mathrm{CO}_{2}$ is a perspective solvent for supercritical fluid extraction (Brunner, 1994). The usual task for researchers is to know the difference between the properties of a desirable compound in a mixture. Main target is to separate key components of mixture, while undesirable compounds should not appear in the raffinate.

Terpenes occur in fixed and essential oils of many plants and many of them have been already studied (Berna at el., 2000; Fonseca at el., 2003; Francisco at el., 2002). Though the topic of the present study is not new in chemical engineering, there are still a lot of missing data concerning vapour-liquid equilibria in systems containing carbon dioxide and terpenes or other compounds with a similar structure. In this work we selected thymoquinone which belongs to oxidized derivatives of aromatic compounds. The structure of thymoquinone is very close to that of $\rho$-cymene and limonene as shown below in Fig. 1.<smiles>Cc1ccc(C(C)C)cc1</smiles><smiles>C=C(C)C1CC=C(C)CC1</smiles><smiles>CC1=CC(=O)C(C(C)C)=CC1=O</smiles>

Fig. 1. The structure of $\rho$-cymene, limonene, and thymoquinone, respectively 
In the paper results of solubility measurements for thymoquinone in supercritical carbon dioxide $\left(\mathrm{SC}-\mathrm{CO}_{2}\right)$ using static method are presented.

\section{MATERIALS AND METHODS}

\subsection{Materials}

Pure $\mathrm{CO}_{2}$ (99.9\%) was purchased from Air-Liquid delivered at pressure up to 60 bar. Thymoquinone (TQ) purchased from Aldrich $\left(\mathrm{C}_{10} \mathrm{H}_{12} \mathrm{O}_{2}\right.$, purity $99 \%$, Germany) was used without further purification.

\subsection{Experimental procedure}

Phase diagrams of high pressure vapour -liquid equilibrium were obtained at pressure ranging from 60 to 120 bars, and at temperature $323.15 \mathrm{~K}$, using a visual method: an eye observation of turbidity (dew or bubble point) that preceded phase separation. A low temperature limit was determined by the melting point of thymoquinone $(320.15 \mathrm{~K})$. Experiments were carried out in an apparatus previously described in the literature (Boget-Łukasik et al., 2008). The main part of the phase equilibrium apparatus is a sapphire cell cylindrical tube. The cell tube is $150 \mathrm{~mm}$ high, with internal diameter 19 $\mathrm{mm}$, and external diameter $32 \mathrm{~mm}$. The sapphire cell was placed inside an air bath and initially connected to the vacuum pump to facilitate loading a sample into the cell using a syringe and to remove the air. Magnetic stirrer was used for mixing its contents. Fig. 2 presents the sapphire-cylinder equilibrium cell with a magnetic bar.

The temperature was measured with a platinum-resistance thermometer with an accuracy of $\pm 0.03 \mathrm{~K}$. The pressure was measured by a manometer Amphenol B12 with accuracy of $0.15 \%$ and a precision of $0.1 \%$. $\mathrm{CO}_{2}$ was initially pumped into the cell through a manual pressure generator of $60 \mathrm{ml}$ capacity. The pressurised cell was left for 1 hour mixing.

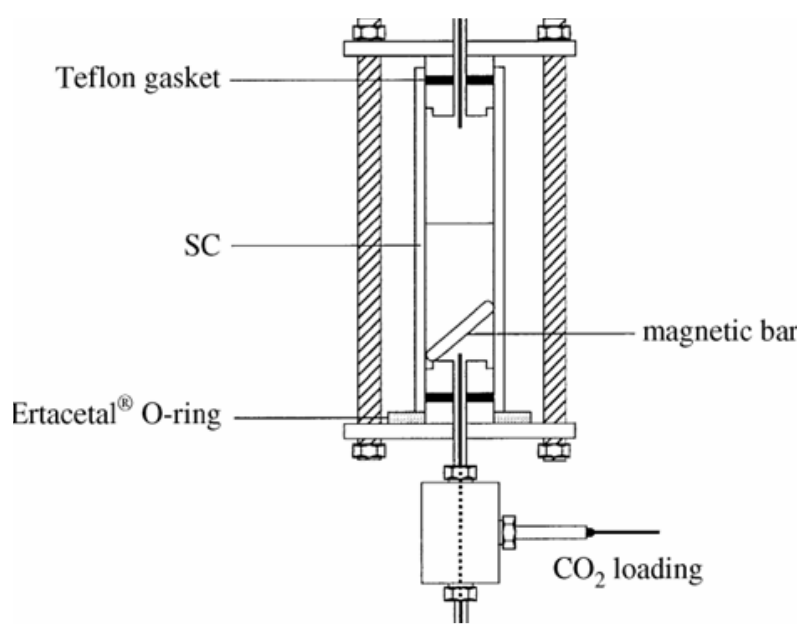

Fig. 2. The sapphire-cylinder equilibrium cell

In each static equilibrium experiment, a heterogeneous solution was continuously heated to a desired temperature maintaining constant stirring until it (eventually) became homogeneous. Then, starting from the one-phase region, the solution was isothermally stirred and the pressure at which it became turbid was taken as a dew/bubble point. 


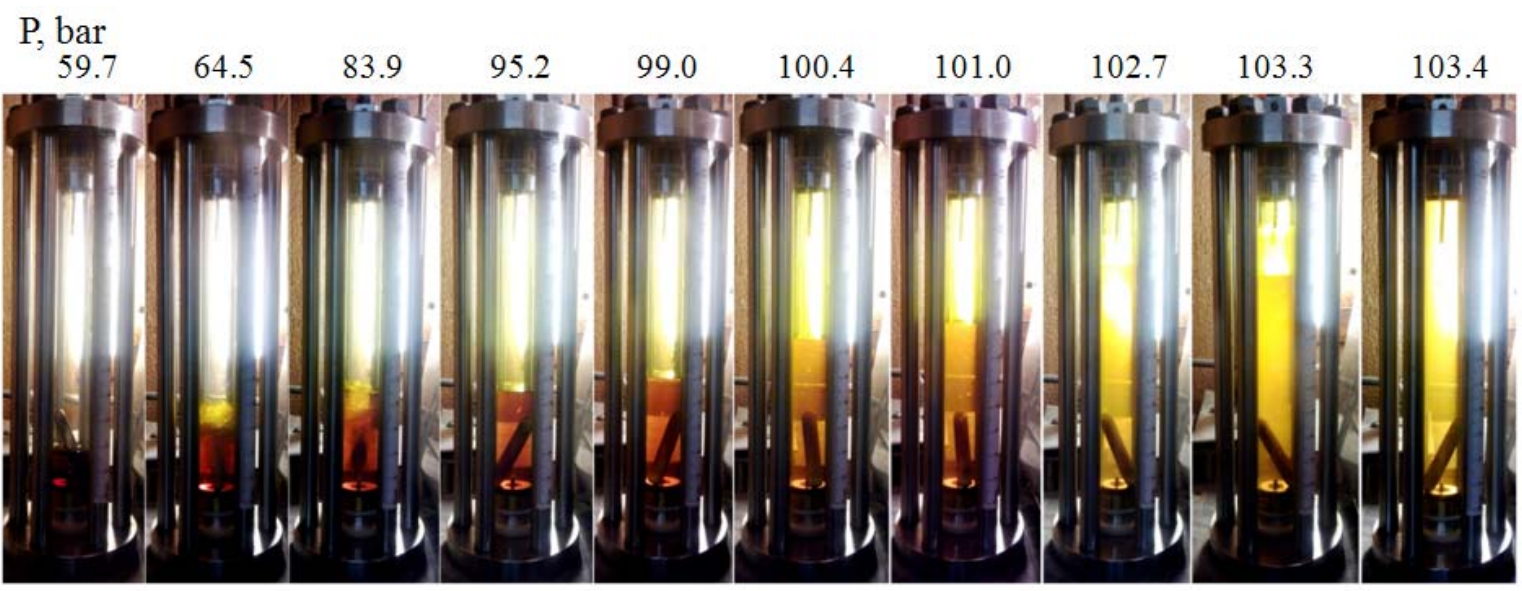

Fig. 3. The view of turbidity (bubble point); binary system of thymoquinone and $\mathrm{SC}-\mathrm{CO}_{2}$

The experiments were performed in two to three runs with the last run being carried out very slowly, meaning that the rate of pressure change near the expected dew/bubble point was no greater than $0.5 \mathrm{bar} / \mathrm{h}$.

\section{RESULTS AND DISCUSSION}

The equilibrium solubility of thymoquinone in $\mathrm{SC}-\mathrm{CO}_{2}$ was obtained at $323.15 \mathrm{~K}$. Experimental data are given in Table 1 and graphically shown in form of $P-x, y$ diagram (Fig. 4), where $x, y$ - liquid and vapour mole fractions, respectively.

Table 1. Experimental data

\begin{tabular}{|l|c|c|c|}
\hline \multicolumn{1}{|c|}{$x_{\mathrm{CO} 2}$} & $y_{\mathrm{CO} 2}$ & $T[\mathrm{~K}]$ & $P[$ bar $]$ \\
\hline dew point & 0.9999 & 323.15 & 102.66 \\
\hline dew point & 0.9933 & 323.15 & 103.45 \\
\hline dew point & 0.9887 & 323.15 & 103.44 \\
\hline critical point & 0.9838 & 323.15 & 103.49 \\
\hline 0.9814 & 0.9965 & 323.15 & 103.42 \\
\hline 0.9762 & 0.9999 & 323.15 & 102.49 \\
\hline 0.9627 & 0.9999 & 323.15 & 101.45 \\
\hline
\end{tabular}

Binary vapour-liquid equilibrium data were fitted to the Soave-Redlich-Kwong equation of state (Soave, 1972) using true Van der Waals mixing rules which were combined with temperature independent parameters using true Van der Waals mixing rules. These mixing rules combined with equation of state set the Soave-Redlich-Kwong equation of state for mixtures. That approach is appropriate for mixtures of compounds with high difference of volatility, being a typical example of supercritical fluid extraction [Wagner at el., 1993]. The modified equation had the following form:

$$
z=\frac{1}{1-b \rho}-\rho \frac{c /(R T)+d-2 \sqrt{c d /(R T)}}{1+b \rho}
$$

where $c, d$ are temperature independent parameters. The constants were transformed using quadratic mixing rules, 


$$
\begin{gathered}
b=\sum_{i} \sum_{j} x_{i} x_{j}\left(1-k_{i j}\right)\left[\left(b_{i}^{1 / 3}+b_{j}^{1 / 3}\right) / 2\right]^{3} \\
c=\sum_{i} \sum_{j} x_{i} x_{j}\left(1-l_{i j}\right) \sqrt{c_{i} c_{j}} \\
d=\sum_{i} \sum_{j} x_{i} x_{j}\left(1-m_{i j}\right)\left[\left(d_{i}^{1 / 3}+d_{j}^{1 / 3}\right) / 2\right]^{3}
\end{gathered}
$$

where $b, c, d$-parameters of the Soave-Redlich-Kwong equation of state; $k_{i j}, l_{i j}, m_{i j}$ - interaction parameters; $P$ - pressure, bar; $R$ - universal gas constant; $T$ - temperature, $\mathrm{K} ; z$-compressibility factor.

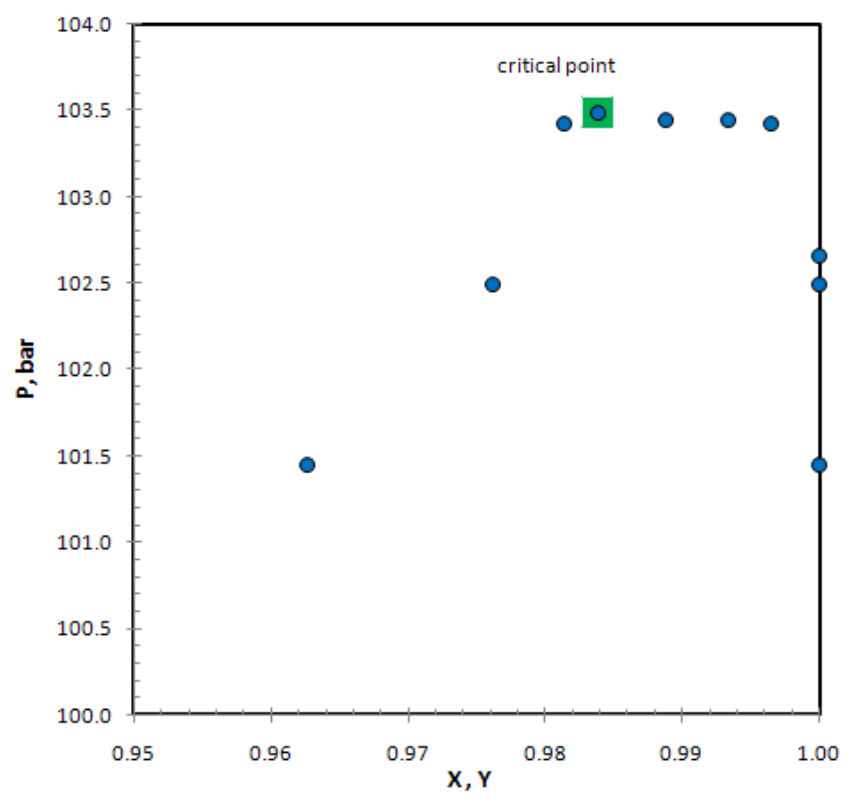

Fig. 4. Experimental points of binary equilibrium thymoqionone $+\mathrm{SC}-\mathrm{CO}_{2}$ at $323.15 \mathrm{~K}$

The values of the interaction parameters $\left(k_{i j}, l_{i j}, m_{i j}\right)$ and pure component constants were found from the critical properties and acentric factors of the studied compounds. The critical properties of thymoquinone are not known. The Gani's method has been used for the prediction of its critical properties (Table 2), because this method contains all chemical groups needed to represent the structure chemical of sesquiterpenes and terpenes (Constantinou at el., 1995).

Table 1. Critical properties of the studied compounds

\begin{tabular}{|l|c|c|c|c|}
\hline Pure component & Molecular weight $[\mathrm{g} / \mathrm{mol}]$ & $T_{c}[\mathrm{~K}]$ & $P_{c}[\mathrm{bar}]$ & $\omega$ \\
\hline $\mathrm{CO}_{2}$ & 44.0 & 304.2 & 71.8 & 0.228 \\
\hline Thymoquinone $\left(\mathrm{C}_{10} \mathrm{H}_{12} \mathrm{O}_{2}\right)$ & 164.2 & $636.8^{\mathrm{a}}$ & 36.5 & $0.787^{\mathrm{a}}$ \\
\hline
\end{tabular}

${ }^{\mathrm{a}}$ Constantinou and Gani method; $\omega$ - acentric factor

The experimental results with fitted predictions shown as $P-x, y$ diagram in Fig. 5. 


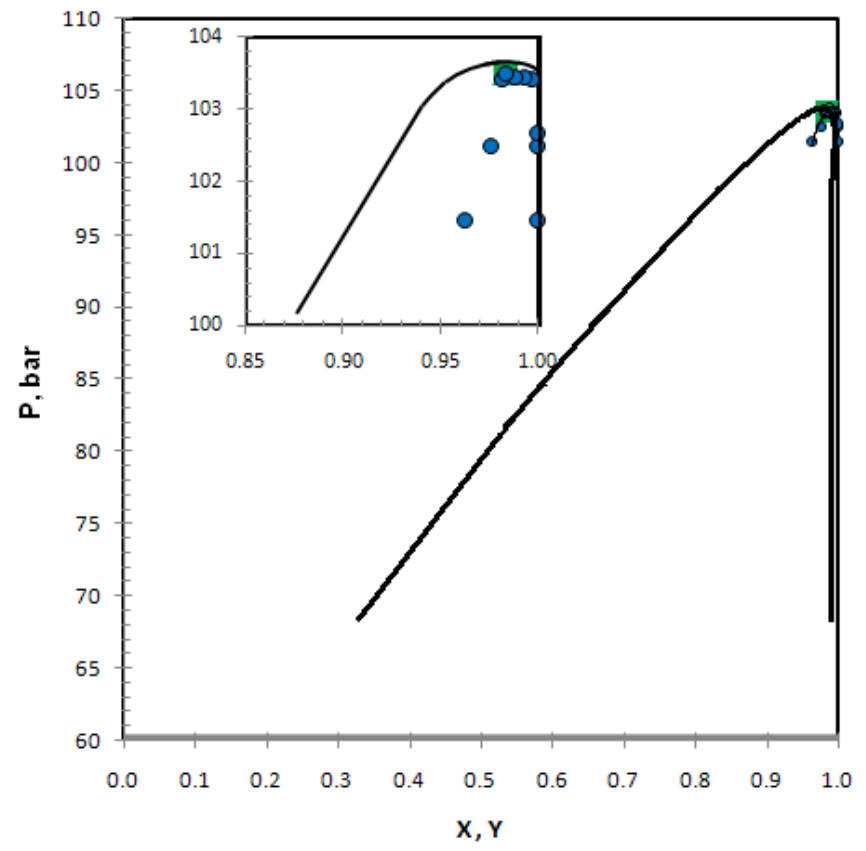

Fig. 5. Prediction of binary equilibrium thymoqionone+SC- $\mathrm{CO}_{2}$ at $323.15 \mathrm{~K}$

\section{CONCLUSIONS}

This is the first report on phase equilibrium behaviour of binary mixture of $\mathrm{SC}-\mathrm{CO}_{2}$ and thymoquinone. Experiments for temperature region below $320.15 \mathrm{~K}$ were not possible to accomplish because of the complexity of vapour-liquid equilibrium equipment and due to the melting point of thymoquinone, which became immediately solid below that temperature. On the other hand temperatures higher than $323.15 \mathrm{~K}$ were not available because of laboratory equipment limitations. In spite of that the most difficult region of binary equilibrium was successfully studied. Critical point at $323.15 \mathrm{~K}$ for the mixture $\mathrm{CO}_{2}$-thymoquinone were obtained at pressure $P=103$ bar and with thymoquinone mole fraction of $x_{\mathrm{TQ}}=0.0162$.

This research was conducted at the Universidade Nova de Lisboa, Faculdade de Cienias e Technologia, Departamento de Quimica under supervision of Prof. Nunes da Ponta and his science group in a frame of LLP Erasmus Trainings. Their interest and support are greatly appreciated.

\section{REFERENCES}

Berna A., Chafer A., Monton J.B., 2000. Solubilities of essential oil components of orange in supercritical carbon dioxide. J. Chem. Eng. Data, 46, 795-799. DOI: 10.1021/je9903101.

Bogel-Łukasik R., Najdanovic-Visak V., Barreiris S., Nunes de Ponte M., 2008. Distribution ratio of lipasecatalyzed reaction products in ionic liquid supercritical $\mathrm{CO}_{2}$ system: Resolution of 2-octanol enantiomers. Ind. Eng. Chem. Res., 47, 4473-4480. DOI: 10.1021/ie0714100.

Brunner G.,1994. Gas extraction: An introduction to fundamentals of supercritical fluids and the application to separation processes. Steinkopff, Darmstadt \& New York, Springer, 30-65.

Constantinou L., Gani R., O’Connel J.P., 1995. Estimation of the acentric factor and the liquid molar volume at 298 K using a new group contribution mehod. Fluid Phase Equilibria, 103, 11-22. DOI: 10.1016/03783812(94)02593-P. 
Fonseca J., Simoes S., Nunes da Ponta M., 2003. An apparatus for high pressure VLE measurements using a static mixer. Results for $\left(\mathrm{CO}_{2}+\right.$ limonene + citral $)$ and $\left(\mathrm{CO}_{2}+\right.$ limonene + linalool $)$. J. Supercritical Fluids, 25 , 7-17. DOI: 10.1016/S0896-8446(02)00085-2.

Francisco J.D., Sivik B., 2002. Solubility of three monoterphens, their mixture and eucalyptus leaf oil in dense carbon dioxide. J. Supercritical Fluids, 23, 11-18. DOI: 10.1016/S0896-8446(01)00131-0.

Soave G., 1972. Equilibrium constants from a modified Redlich-Kwong equation of state. Chem. Eng. Science, 27 (6), 1197-1203. DOI: 10.1016/0009-2509(72)80096-4.

Wagner Z., Pavlicek J., 1993. Vapour-liquid equilibrium in the carbon dioxide $\rho$-cymene system at high pressure. Fluid Phase Equilibria, 90, 135-141, DOI: 10.1016/0378-3812(93)85008-A.

Received 04 April 2013

Received in revised form 31 May 2013

Accepted 01 June 2013 